\title{
THE BIOLOGICAL OPTIMAL LEVEL OF THE ARAFURA SHRIMP FISHERY
}

\author{
Purwanto \\ Research Center for Fisheries Management and Conservation, Ancol-Jakarta \\ Received October 26-2010; Received in revised form October 22-2010; Accepted November 4-2010
}

\begin{abstract}
This paper briefly describes the past development of the shrimp fishery in the Arafura Sea, including intensity of illegal fishing, and presents the impact of increasing fishing pressure on the quantity of catch and biomass. The maximum sustainable yield and the optimum fishing effort are estimated. Estimate of catch losses caused by illegal fishing is also presented.
\end{abstract}

KEYWORDS: $\quad$ shrimp fishery, illegal fishing, maximum sustainable yield

\section{INTRODUCTION}

Arafura Sea is one of the most productive fishing grounds in Indonesia. The shallow waters of this fishing ground are highly productive (Bailey et al., 1987), as this area is regularly enriched by nutrient rich upwelling and nutrient inputs from river flow. The Arafura Sea is one of the few areas within the Indonesian EEZ where nutrient rich upwelling occurs. In the Banda and in the Arafura Seas upwelling develops under the influence of the southeast monsoon (Wyrtki, 1961). Meanwhile, water mass flowing in the large rivers carries nutrient into the Arafura Sea from the dense forest in the hinterland of Papua during rainy season. Nutrient is also transported to the Arafura Sea from the dense mangrove area along the west coast of Papua (Sadhotomo et al., 2003).

The stock size of shrimps in the Arafura Sea was estimated to be about $45 \%$ of the total size of shrimp stocks in Indonesia (Indonesian Ministry of Marine Affairs and Fisheries of Indonesia, 2006). The trawlable area for shrimp fishing in the Arafura Sea was about $74,000 \mathrm{~km}^{2}$, with water depths ranging from $10-50 \mathrm{~m}$ (Naamin, 1984; Sadhotomo et al., 2003). The commercial fishing operation targeting shrimps in the Arafura Sea was started in the early 1970s after the findings rich shrimp stocks and the introduction of the double rigged shrimp trawl in that fishing area during the late 1960 s, prompted by strong international demand for shrimp (Bailey et al., 1987). Trawl became one of the main fishing gears in Indonesia as it was the most productive fishing gear for demersal fisheries.

The fishing capacity of trawl fleet in the Arafura Sea was continuously developed. This has substantially reduced the abundance of demersal stocks in this area. Naamin (1984); Badrudin et al. (2002) estimated optimal effort required to produce optimal yield from the utilisation of the shrimp stock in the Arafura Sea. Meanwhile, Widodo et al. (2001) evaluated the development of demersal fishery, including shrimp fishery, in the Arafura Sea and concluded that the stocks of demersal fishes and shrimps in this area were over exploited. The over exploitation of shrimp stock in the Arafura Sea has threatened sustainability of these resources (Widodo et al., 2001).

The condition of the Arafura shrimp fishery had been worsened by illegal fishing practices undertaken by Indonesians and foreigners resulting in economic losses and a fishery management failure. However, studies undertaken previously did not taken into account the magnitude of the illegal fishing practices in the assessment of shrimp stock and the optimal fishing effort. If the level of illegal fishing practice was substantial, the result of assessment would be bias, and management measures formulated on the basis of the assessment would be misleading .

Therefore, this study estimated the intensity of illegal fishing practice in the Arafura shrimp fishery. The result of this estimation then used to assess the optimal utilisation of shrimp stock in the Arafura Sea and the impact of the illegal fishing on the fishery.

\section{MATERIALS AND METHODS}

Data used in this article consist of the number of shrimp trawlers and fish trawlers, and the catch of shrimps per unit vessel, during the year 1996-2005. Fishing power of the fish trawler to catch shrimps was about $25 \%$ of the shrimp trawler. Therefore, fishing effort in the Arafura shrimp fishery was standardized in the number of shrimp trawlers. Sources of data on the number of fishing vessels holding fishing license were (i) the statistic of Indonesian-flag and Foreignflag Fishery Vessels (Directorate General of Fisheries, 1998), (ii) Indonesian Fisheries Statistic (Directorate General of Fisheries 1999, 2000; Directorate General of Capture Fisheries, 2001), and (iii) various 
unpublished records of data on permitted fishing vessels in 1999-2005, from the Directorate of Business Services of the Directorate General of Capture Fisheries. Meanwhile, data on the catch of shrimps per unit shrimp trawler were from the Indonesian Shrimp Fishery Association.

Analysis undertaken on the basis of the Schaefer (1957) production model. The model is also discussed in Clark (1976). The equations of the model used here are as follows:

Natural population growth function:

$G(x)=r . x .(1-x / K)$

Biomass function:

$x=K-(q \cdot K / r) \cdot E$

Production function:

$h=(q \cdot K) \cdot E-\left(q^{2} \cdot K / r\right) \cdot E^{2}$

Catch per unit effort function:

$U=(q \cdot K)-\left(q^{2} \cdot K / r\right) \cdot E$

where:
$\mathrm{x}=$ the stock biomass
$r=$ the natural growth rate of population
$\mathrm{q}=$ catchability coefficient
$\mathrm{K}=$ the environmentally limited maximum biomass or carrying capacity
$E=$ fishing effort
$\mathrm{H}=$ Yield or total catch

Maximum sustainable yield and fishing effort to produce maximum sustainable yield $\left(E_{M S Y}\right)$ can be estimated by using the following equations:

$$
\begin{aligned}
& M S Y=r . K / 4 \\
& E_{M S Y}=r / 2 q .
\end{aligned}
$$

Biological parameters $r$, K, and q were estimated using the value of coefficients $a$ and $b$ of the catch per unit effort function as follows:

$$
\mathrm{U}=\mathrm{a}-\mathrm{b} \cdot \mathrm{E}
$$

Coefficients $a$ and $b$ of this equation were estimated by ordinary least square. Then, a method developed by Fox (1975) was used to estimate parameters q, r, and $\mathrm{K}$ as follows: $q_{t}=\ln \left|z_{t} U_{t}^{1} m \quad \frac{1}{b} / z_{t} U_{t}^{1} \frac{m}{b}\right| \frac{1}{b} \mid / z_{t} m \quad z_{t} \ldots \ldots .(7$

where:

$q_{t}=$ estimated catchability coefficient in year $\mathrm{t}$

$z_{t}=-\mathrm{a} / \mathrm{b}-\left(\mathrm{E}_{\mathrm{t}}+\mathrm{E}_{\mathrm{t}+1}\right) / 2$

$U_{t}=$ catch per unit effort in year $t$

$\mathrm{m}=$ constant parameter with a value of 2 for the Schaefer model

$E_{t}=$ fishing effort in year $t$

The average catchability coefficient over $n$ years (q), parameters K, and r were estimated as follows:

$q=\exp \left[\sum_{t=1}^{n-1} \ln \left|q_{t}\right| /(\mathrm{n}-1)\right]$

$\mathrm{K}=\mathrm{a} / \mathrm{q}$

$\mathrm{r}=\mathrm{q} \cdot \mathrm{a} / \mathrm{b}$

As shrimp stock in the Arafura sea was also fished by vessels operated illegally, the number of those vessels was estimated on the basis of the data on illegal fishing practices in the year 2003-2008 from the Directorate General of Fisheries Surveillance. A trend analysis was undertaken to estimate the intensity of illegal fishing in the Arafura shrimp fishery. The relationship between the percentage of the number of fishing vessels operated without license in year $t$ and the corresponding year was analysed using selected equation as follows:

$$
y_{t}=a_{0}+a_{1} \cdot t+a_{2} \cdot t^{2}+a_{3} \cdot t^{3}
$$

where:

$$
\begin{aligned}
y_{t}= & \text { the percentage of the number of fishing } \\
& \text { vessels operated without license in year } t \\
t= & \text { the year, } 6 \text { for } 1996, \ldots, \text { and } 18 \text { for } 2008
\end{aligned}
$$

The number of illegal fishing vessels was estimated by using the following equation:

$$
V_{\text {fit }}=\left\{\left[100 /\left(100-y_{t}\right)\right]-1\right\}^{*} V_{\text {frt }}
$$

where:

$V_{\text {frt }}=$ the number of permitted fishing vessels operating fish trawl in year $t$

$V_{\text {fit }}=$ the number of fishing vessels operating fish trawl without license in year $\mathrm{t}$ 


\section{RESULTS AND DISCUSSION}

\section{Results}

\section{Development of Fishing Fleet}

The main fishing gear to utilize shrimp resources in the Arafura Sea was the double rigged trawl. This fishing gear was introduced to exploit shrimp resources in the Arafura Sea in early 1970. The fishing operation of shrimp trawlers was concentrated in the waters along the western coast of Papua, and the waters around Aru and Dolak Islands, as shown by the recorded tracks of the vessels presented in Appendix 1. Another gear was the otter trawl, even though the main target of this gear was fish stocks.

The development of fleet permitted to catch shrimps in the Arafura Sea is shown in Figure 1. The total number of shrimp trawlers had increased from 168 unit in 1986 to 526 units in 2000, then declined to 301 units in 2005. Meanwhile, the number of vessels operating fish trawl increased from seven units in 1986 to 805 units in 2001, then declined to 781 units in 2005 (Figure 1).
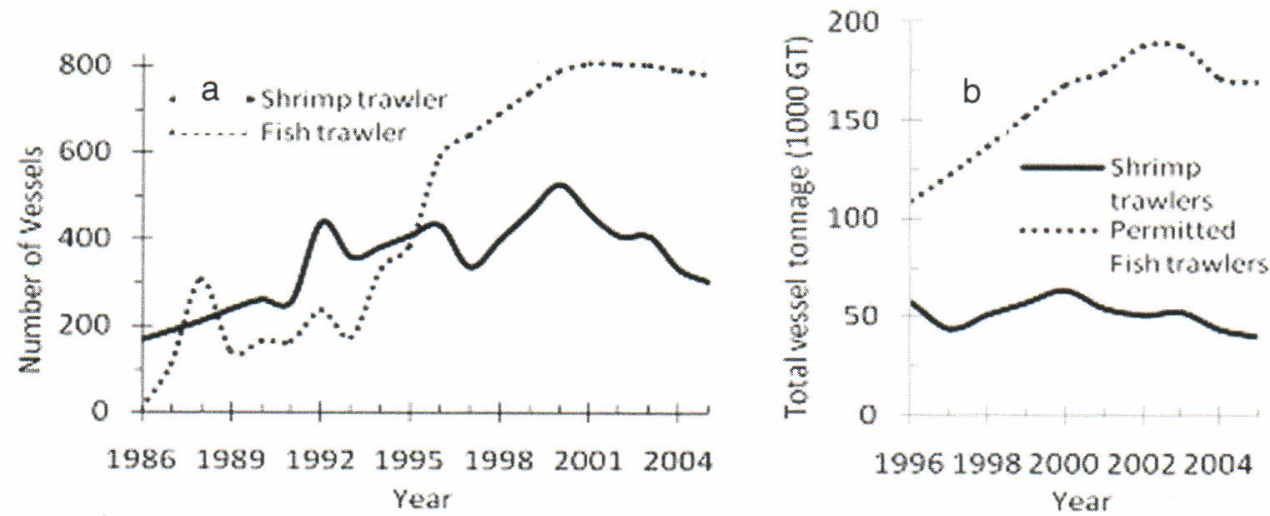

Figure 1. (a) The number of trawl vessels granted license to operate in Arafura Sea in 1986-2005 and

(b) their total tonnage during 1996-2005.

The average size of shrimp trawlers granted fishing license was relatively stable at about 130 GT during the year 1996-2005. Meanwhile, the average size of fish trawlers operated legally in Arafura Sea increased from 184 GT in 1996 to 218 GT in 2005.

There was illegal fishing practices in Arafura shrimp fishery that has been conducted before 1996. The highest intensity of the illegal fishing practices in this area, as informed by the Indonesian shrimp

fishery association and some skippers, occurred in the year 1999-2000. The Association estimated that the intensity of illegal fishing in 1996 was similar to the intensity in 2004. A guesstimate of the number of fishing vessels operated in the Arafura Sea without license was about $5 \%$ of the total number of vessels targeting shrimp stock in 1996. Meanwhile, the proportion of the number of fishing vessels operated without fishing license in Arafura Sea was about 17\% in 2003 (Figure 2).

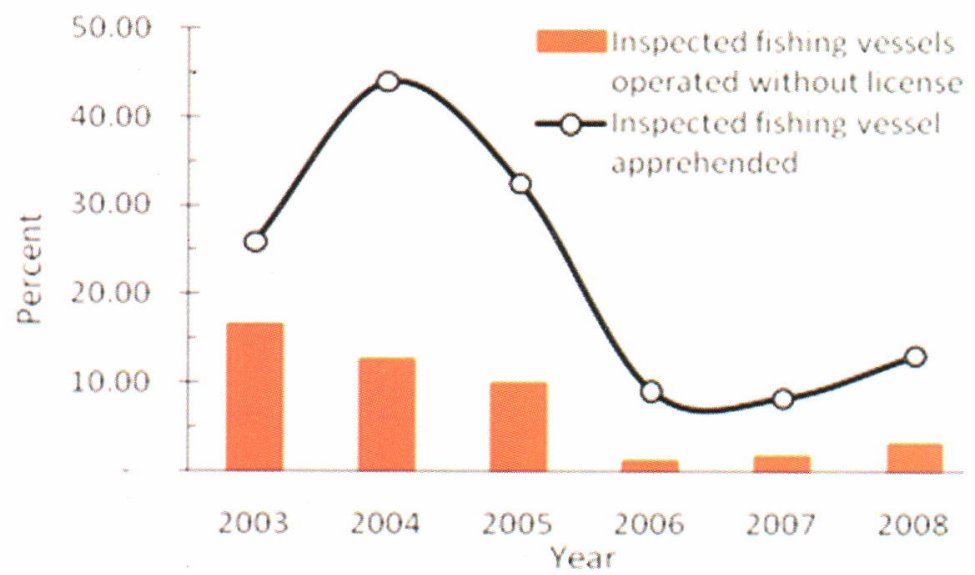

Figure 2. The proportion of fishing vessels inspected by the MOMAF's Fisheries Surveillance Vessels that involved in illegal fishing and had been apprehended, and the proportion of the inspected fishing vessels that were found to fish without license, 2003-2008. 
The trend of the intensity of illegal fishing in the Arafura shrimp fishery, as indicated by the percentage of the number of fishing vessels operated without license, was represented by the following equation:

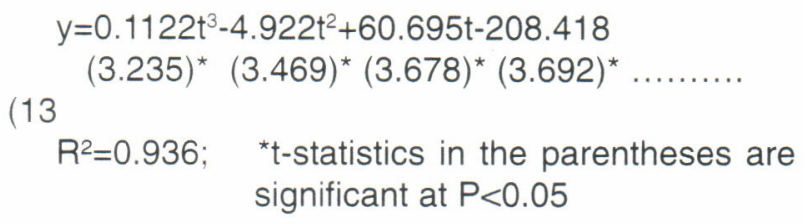

$R^{2}=0.936 ; \quad$ *t-statistics in the parentheses are significant at $\mathrm{P}<0.05$

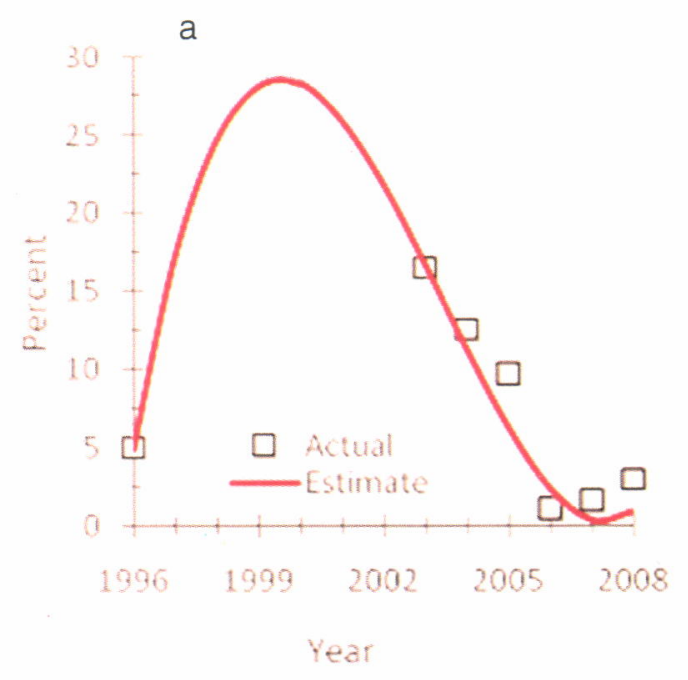

By using equation (13), the proportion of the fishing vessels operated in the Arafura Sea without license and the number of these illegal fishing vessels were estimated and presented in Appendix 2 and graphically shown in Figure 3 . The highest percentage of the number of fishing vessels operated without license was estimated to be $28.3 \%$ in 2000 (Figure 3a). Therefore, the number and the total vessel tonnage of this illegal fishing vessels in 2000 was about 312 vessels and $66,700 \mathrm{GT}$, respectively (Figure $3 \mathrm{~b}$ ). The intensity of the illegal fishing decreased to the minimum by 2006.

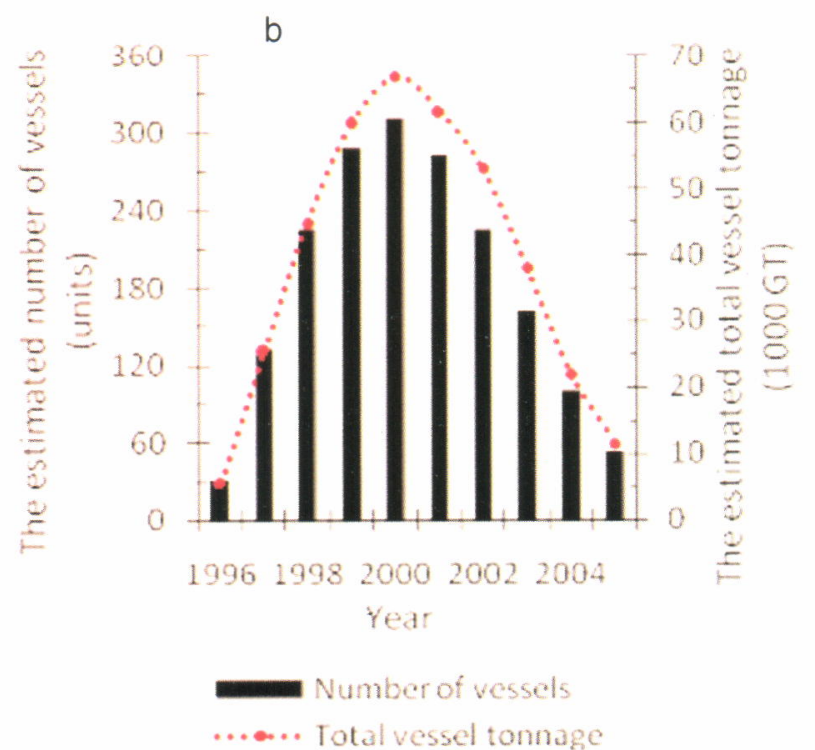

Figure 3. (a) the proportion of the vessels operating fish trawl without license in 1996-2008 and (b) the estimated number and the total tonnage of vessels operating fish trawl without license in 1996-2005, in the Arafura Sea.

\section{Development of Fishing Effort, Catch Per Unit Effort and Total Catch}

As shown in Appendix 3 the total fishing effort increased to the maximum (equal to 801 shrimp trawler units) in 2000 , then continuously declined to 509 units in 2005 (Figure 4a). On the contrary, the observed catch per unit effort decline to the minimum (about 57.5 tonnes/vessel/year) in 2000 , then increased to 89.5 tonnes/vessel/year in 2005. The relationship between the catch per unit effort $(U)$ and the fishing effort (E) in the Arafura shrimp fishery was significantly represented by the following equation:

$$
\begin{aligned}
& U=148,970-0.121 E \\
& (20.377)^{\star \star}(10.617)^{\star \star} \\
& R^{2}=0.934 ;{ }^{* \star} \text { t-statistics in the parentheses }
\end{aligned}
$$

The estimated catch per unit effort was also at the minimum (about 51.9 tonnes/vessel/year) in 2000. Meanwhile, the estimated catch per unit effort in 2005 was about 87.1 tonnes/vessel/year (Figure 4b).

The biological parameters $\mathrm{q}, \mathrm{K}$, and $\mathrm{r}$, estimated on the basis of the value of the coefficients of Equation (15), are presented in Table 1. 

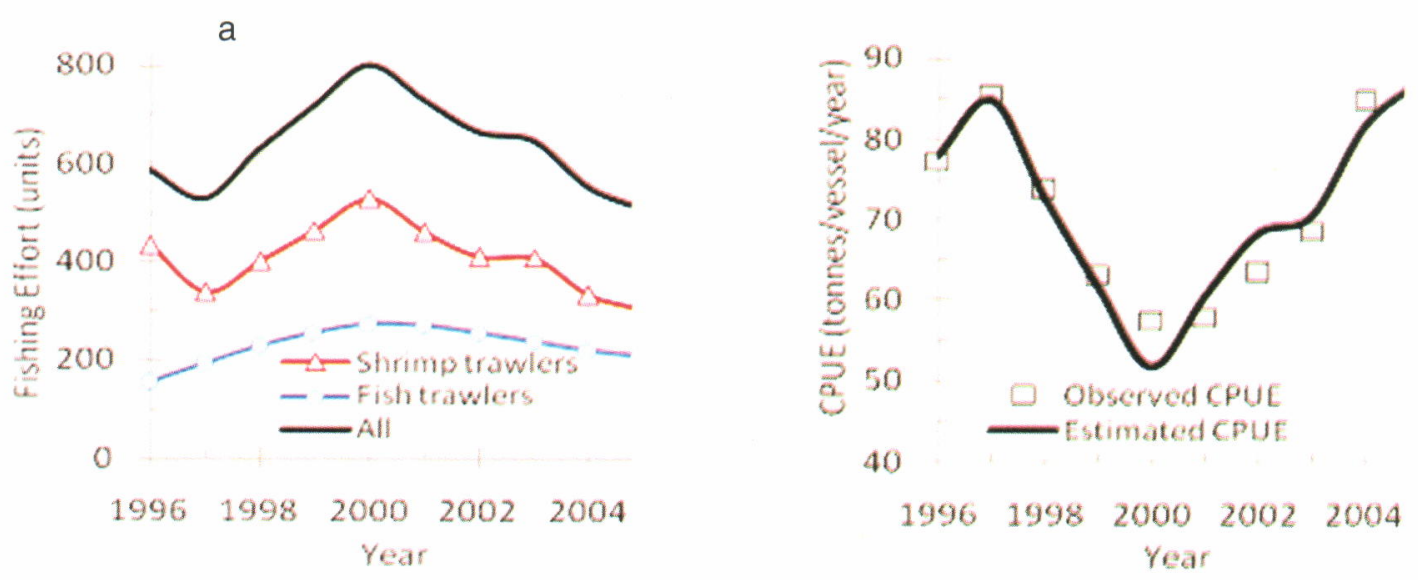

Figure 4. (a) The fluctuation of fishing effort and (b) catch per unit effort in the Arafura shrimp fishery, 1996-2005.

Table 1. The value of biological parameters of population growth and production of shrimp stock in the Arafura Sea

\begin{tabular}{cc}
\hline Parameter & Value \\
\hline $\mathrm{q}$ & 0.001383 \\
$\mathrm{~K}$ & 107,752 \\
$\mathrm{r}$ & 1.7021 \\
\hline
\end{tabular}

The vessel productivity of fishing vessels in in the Arafura shrimp fishery, as indicated by the catch per unit effort, decreased with increasing fishing effort (Figure 5a). Similarly, the shrimp biomass $(x)$ in the Arafura Sea also decreased with increasing fishing effort (Figure 5b). The relationship between shrimp biomass and fishing effort in the Arafura shrimp fishery was represented by the following equation:
$X=107,752-87.521 \mathrm{E}$

An increase in fishing effort decreased the stock abundance or biomass of shrimps in the Arafura Sea (Figure $5 \mathrm{~b}$ ). Changes in the shrimp biomass results in different natural growth rate of shrimp stock [G(x)] as represented by the following equation:

$$
\mathrm{G}(\mathrm{x})=1.702 \times(1-\mathrm{x} / 107,752)
$$

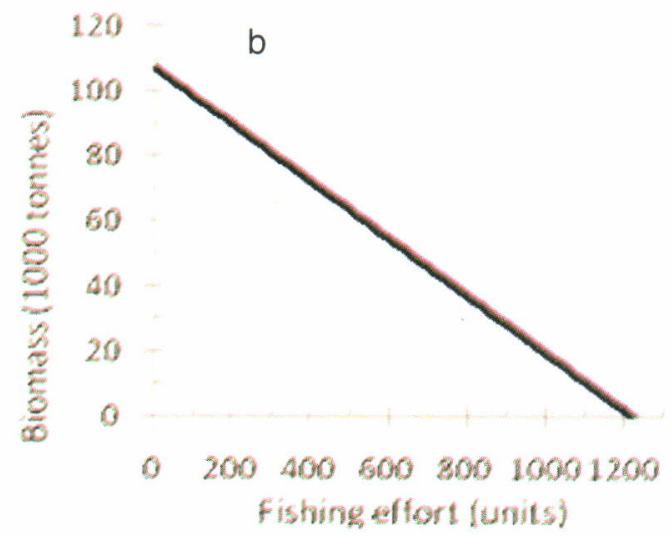

Figure 5. The relationships between (a) shrimp catch per unit effort and fishing effort and (b) shrimp biomass and fishing effort in the Arafura shrimp fishery.

In early development of the fishery, increasing fishing effort decreased the shrimp biomass (Figure $5 b$ ), which in turn, increased the natural biomass growth rate (Figure 6a). The natural growth rate of shrimp stock increased to the maximum rate with further decrease in the biomass or stock size (Figure $6 a)$, resulting from further increase in the fishing effort. After reaching the maximum rate, decreasing the biomass resulted in lower growth rate (Figure 6a). 

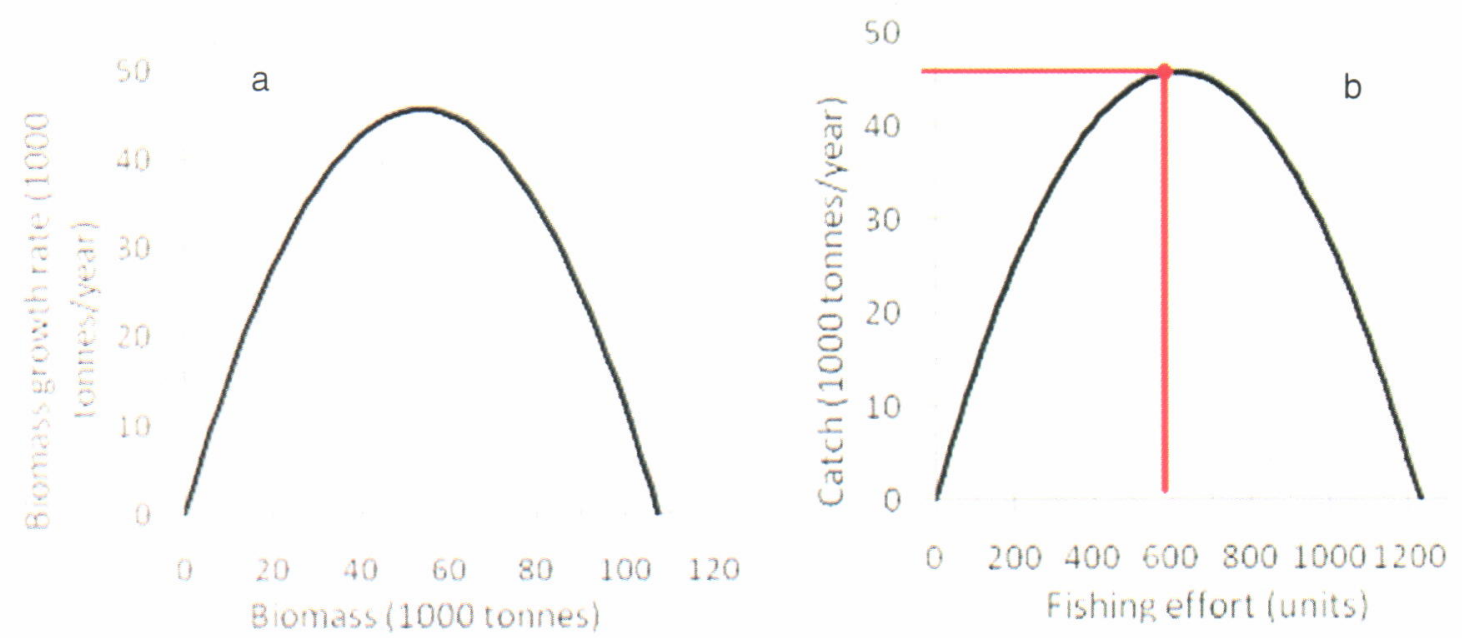

Figure 6. The relationships between (a) biomass growth rate and biomass and (b) shrimp catch and fishing effort in the Arafura shrimp fishery.

Similarly, the catch or yield increased to the maximum level with increasing fishing effort (Figure $6 \mathrm{~b})$. After attaining the maximum sustainable yield, increasing fishing effort resulted in lower catch. The relationship between the quantity of catch and fishing effort in the Arafura shrimp fishery was as follows:

$$
h=148,970 E-0.121 E^{2}
$$
$(17$

Table 2 .
The estimated optimal levels of fishing effort, biomass, harvest, and catch per unit effort in the Arafura shrimp fishery are presented in Table 2 . The maximum sustainable yield of the shrimp stock in the Arafura Sea was about 45,850 tonnes/year resulting from the operation of 616 units of shrimp trawlers, this was the biologically optimal level of fishing effort $\left(E_{M S Y}\right)$.

\begin{tabular}{|c|c|c|c|c|c|c|}
\hline & \multirow[b]{2}{*}{ Units } & \multicolumn{3}{|c|}{ Status of shrimp fishery } & \multirow{2}{*}{$\begin{array}{l}\text { SIUP } 2007 \text { and } \\
\text { estim ated impacts }\end{array}$} & \multirow{2}{*}{$\begin{array}{c}\text { Biological } \\
\text { optimal leve }\end{array}$} \\
\hline & & $\begin{array}{l}\text { yeal } \\
2000\end{array}$ & $\begin{array}{l}\text { year } \\
2005\end{array}$ & $\begin{array}{l}\text { yeal } \\
2007\end{array}$ & & \\
\hline Shrimp trawlers & Vessels & 526 & 301 & 341 & 440 & \\
\hline Fish trawlers & Vessels & 789 & 781 & 500 & 1112 & \\
\hline Illegal vessels & Vessels & 316 & 61 & 9 & & \\
\hline Fishing effort & standard vessels & 801 & 509 & 468 & 718 & 616 \\
\hline Biomass & Tonnes & 37628 & 63,170 & 66,779 & 44,912 & 53876 \\
\hline Harvest & tonnesyear & 41681 & 44,487 & 43221 & 44582 & 45,851 \\
\hline CPUE & tonne shessel & 52.0 & 87.3 & 92.3 & 62.1 & 74.5 \\
\hline
\end{tabular}

The actual fishing effort of fishing fleet operated in the Arafura shrimp fishery, taking into account fishing vessels operated illegally, was higher than the $\mathrm{E}_{\mathrm{MSY}}$ during 1998-2003. In 2003, the effort was 647 units. Meanwhile, the lowest and the highest ones were 628 units in 1998 and 801 units in 2000, respectively (Figure 4a). Therefore, it could be concluded that the Arafura Sea shrimp biomass was over exploited during that period. As consequences, the catch per unit effort was lower than the catch per unit effort at maximum sustainable yield (Figure 5a), and the yield was lower than the maximum sustainable yield (Figure 6b). During 2004-2007, the shrimp stock in the Arafura Sea was biologically under exploited as operated fishing effort declined to the levels lower than the $E_{M S Y}$ (Figure 4a).

The operation of fishing vessels without license created two kinds of direct losses, namely a decrease in the catch of shrimps landed by permitted vessels and a decrease in the domestic supply of fishes. In 2003 , total fishing effort was 647 vessels producing 45.7 thousand tonnes of shrimps (Table 3). However, 2.9 thousand tonnes of shrimps was taken away by 41 vessels that was operated illegally, without fishing license. They could export the catches directly from 
fishing ground to the market overseas. This resulted in a decrease in the domestic supply of shrimps. Meanwhile, 606 vessels holding fishing license landed 42.8 thousand tonnes of their catches in Indonesian ports before exportation. If illegal fishing practice did not exist and shrimp stock was utilised by permitted vessels only, that was 606 units, this vessels would land 45.8 thousand tonnes of shrimps. A decrease in the catch of shrimps landed by permitted vessels, amounting of about three thousand tonnes in 2003, was an impact of additional fishing pressure resulting from the operation of illegal fishing vessels that caused shrimp stock depletion.

The fishing effort in the Arafura shrimp fishery could increase again to the level higher than the $E_{M S Y}$ as the Indonesian Directorate General of Capture Fisheries had issued a number of fishing allocation certificates (Surat ljin Usaha Perikanan) to provide fishing companies with additional fishing allocation. By 2007, the total fishing allocation that had been provided to the fishing companies consisted of 440 shrimp trawlers and 1112 fish trawlers (Directorate General of Capture Fisheries, 2007) that could result in 718 units of fishing effort, the level higher than the $E_{M S Y}$. In 2007, only 341 shrimp trawlers and 500 fish trawlers had been operated (Directorate General of Capture Fisheries, 2007), resulting in 466 units of fishing effort. An amount of 252 units was latent effort that would increase fishing effort to 718 units when new fishing allocation consisting of 99 shrimp trawlers and 612 fish trawlers were operated. If fishing effort was 718 units, biomass, catch per unit effort, and harvest would decrease to the levels lower than their optimal levels (Table 2).

\section{Discussion}

Arafura Sea is the most important fishing ground for shrimp fishery in Indonesia, as it is very productive area for shrimp fishery that attracted fishers to operate in this area for fishing either in legal or illegal ways. The optimal catch of penaeid shrimps resulting from the Arafura Sea as estimated in this study was about 45.850 tonnes/year. It is close to the optimal level of the penaeid catch stated in the Decree of Agriculture Minister number No.995 of 1999, that is 43,100 tonnes per year. The difference between those two values is $6.4 \%$. The difference may be caused by the inclusion of the fishing effort of illegal trawlers in the estimation of optimal catch undertaking in this study.

The total variability of annual catches harvesting from certain stocks is affected not only by fishing effort variations but also by environment variations (Freon, 1986). The result of a study conducted by Purwanto
(1997), using modified von Bertalanffy growth model, showed that growth of Penaeus monodon was affected by various environmental variables, namely salinity, water temperature, and water transperancy. Meanwhile, Okey \& Poloczanska (2008), from their review, identify that there are likely to be significant climate change impacts on the biological, economic, and social aspects of prawn fisheries of northern Australia. As the study presented here did not take into account environmental variables that may affect the catch of shrimps from Arafura Sea, it is suggested to incorporate the environmental variables into the model used in the future assessment of shrimp stock in the Arafura Sea.

The result of this study also shows the positive impact of the improvement on the fisheries management undertaking by the Indonesian Government during 2000-2005. The improvement covered activities to improve fisheries licensing services, to re-register all fishing licenses and to increase fisheries surveillance capacity and activity, and law enforcement. The objectives of this activities were minimising the number of illegal fishing vessels operated by Indonesian fishing companies and minimising the intensity of illegal fishing practices in the Indonesian waters in order to optimise the utilisation of fishery resources for Indonesians' welfare. Therefore, the number and the total tonnage of the shrimp trawl and fish trawl vessels that could be granted fishing licences decreased during year 20012005. The intensity of the illegal fishing practices also decreased during that period. The decrease in illegal fishing practices decreased catch losses. Consequently, productivity of fishing vessels, as indicated by catch per unit effort, increased considerably. Unfortunately, the intensity of illegal fishing practices by foreign vessels increased since 2007. This was a coincidence that the Government of Indonesia did not renew fishing licenses for foreign vessels since 2007 . However, this problem could be solved by appropriate tactic and strategy on fisheries surveillance and consistent law enforcement.

Further improvement on fisheries management especially on the management of licensing services should be undertaken to avoid the over allocation on fishing capacity, as happened in 2007 , in order to avoid possible over exploitation on shrimp stock. This improvement would cover at list the data and information management and the decision mechanisms. When deciding the amount of vessels that would be granted licences to harvest shrimps, however, the impact on other species should be taken into account, as species composition of catches resulting from the operation of shrimp trawlers and

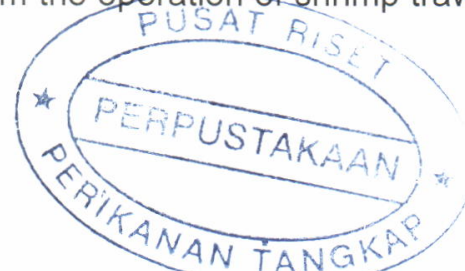




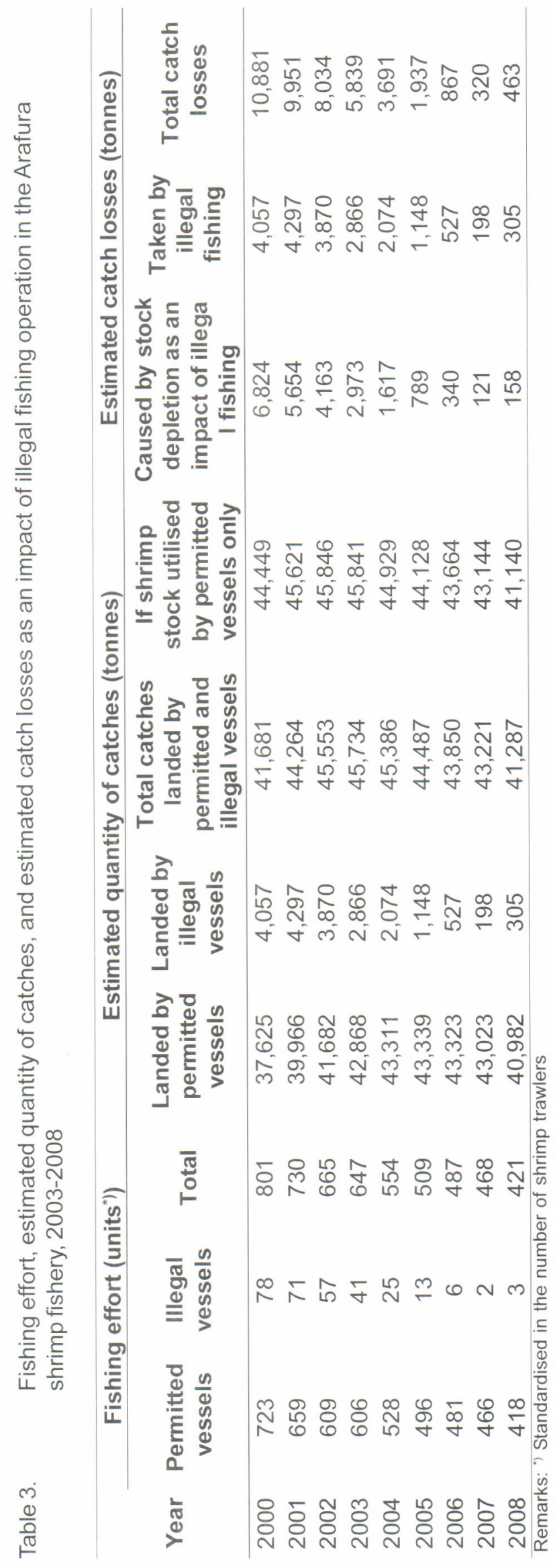


fish trawlers consists of shrimps and demersal fishes (Widodo et al., 2001). The optimal number of vessels that would be granted fishing licences to operate in the Arafura Sea could be estimated by using a multispecies multigear fishery model, in which the result of this study could be incorporated.

\section{CONCLUSIONS}

1. On the basis of the result of the analysis shows, it can be concluded that the maximum sustainable yield of the shrimp stock in the Arafura Sea was about 45,850 tonnes/year resulting from the operation of 616 units of shrimp trawlers. Although, the Arafura shrimp stock were over exploited in 2000 , as an impact of mis-management and illegal fishing practices, the improvement on the fisheries management undertaking by the Indonesian Government during 2000-2005 had resulted in the positive impact. In 2007, the shrimp stock had recovered from over exploitation. However, fishing effort in the Arafura shrimp fishery could increase again to the level higher than the optimal level as total fishing allocation in SIUP that had been provided to the fishing companies was higher than the optimal allocation (over allocation) by 2007.

2. Further improvement on fisheries management especially on the management of licensing services should be undertaken to avoid the over allocation in order to avoid possible over exploitation on shrimp stock.

\section{REFERENCES}

Bailey, C., A. Dwiponggo, \& F. Marahudin. 1987. Indonesian marine capture fisheries. ICLARM Studies and Reviews 10.

Badrudin, B. Sumiono, \& N. Wirdaningsih. 2002. Laju tangkap, hasil tangkapan maksimum (MSY), dan upaya optimum perikanan udang di Laut Arafura. Jurnal Penelitian Perikanan Indonesia. 8 (4): 2329.

Clark, C. W. 1976. Mathematical Bioeconomics: The Optimal Management of Renewable Resources. John Wiley and Sons. New York.

Directorate General of Capture Fisheries. 2007. Penyusunan Evaluasi Alokasi dan Realisasi Usaha Penangkapan Perorangan atau Perusahaan Berbendera Indonesia dan Asing (The Evaluation of Alocation and Realisation of Indonesian and Foreign Fishing Business). Jakarta.
Fox, W. W. 1975. Fitting the generalized stock production model by least squares and equilibrium approximation. Fishery Bulletin. 73 (1): 23-37.

Freon, P. 1986. Introduction of environmental variables into global production models. Int. Symp. Long Term Changes Mar. Fish Pop. Vigo.

Naamin, N. 1984. Dinamika populasi udang jerbung (Penaeus merguiensis de Man) di perairan Arafura dan alternatif pengelolaannya [Population dynamics of banana shrimps (Penaeus merguiensis de Man) in the Arafura waters and its management alternatives]. Disertasi Doktor. Fakultas Pasca Sarjana. institut Pertanian Bogor. 281 pp.

Okey, T. A. \& E. S. Poloczanska. 2008. Northern fisheries. In Hobday, A. J., E. S. Poloczanska, \& R. J. Matear (eds). Implications of Climate Change for Australian Fisheries and Aquaculture: A Preliminary Assessment. Report to the Department of Climate Change. Canberra. Australia. August 2008.

Purwanto. 1997. Economic optimisation in prawn farming. Ph.D. Thesis. James Cook University of North Queensland, Australia. 293 pp.

Sadhotomo, B., P. Rahardjo, \& Wedjadmiko. 2003. Pengkajian kelimpahan dan distribusi sumber daya demersal dan udang di perairan Laut Arafura [An assessment of the abundance and distribution of demersal and shrimp stocks in the Arafura Sea]. Prosiding Forum Pengkajian Stok Ikan Laut 2003. Pusat Riset Perikanan Tangkap. Departemen Kelautan dan Perikanan. Jakarta.

Schaefer, M. B. 1957. Some considerations of population dynamics and economics in relation to the management of marine fisheries. Journal of the Fisheries Research Board of Canada. 14: 66981.

Widodo, J., Purwanto, \& S. Nurhakim. 2001. Evaluasi Penangkapan Ikan di Perairan ZEEI Arafura: Pengkajian Sumber Daya Ikan Demersal [An Evaluation of Fishery in the IEEZ in Arafura: Assessment of Demersal Fishery Resources]. Direktorat Jenderal Perikanan. Departemen Kelautan dan Perikanan. Jakarta.

Wyrtki, K. 1961. Physical Oceanography of the Southeast Asian Waters. NAGA Report. 2: 195 pp. 
Appendix 1. The tracks of the operation of shrimp trawlers in Arafura Sea, as recorded by VMS facilities, October 2004 until October 2005

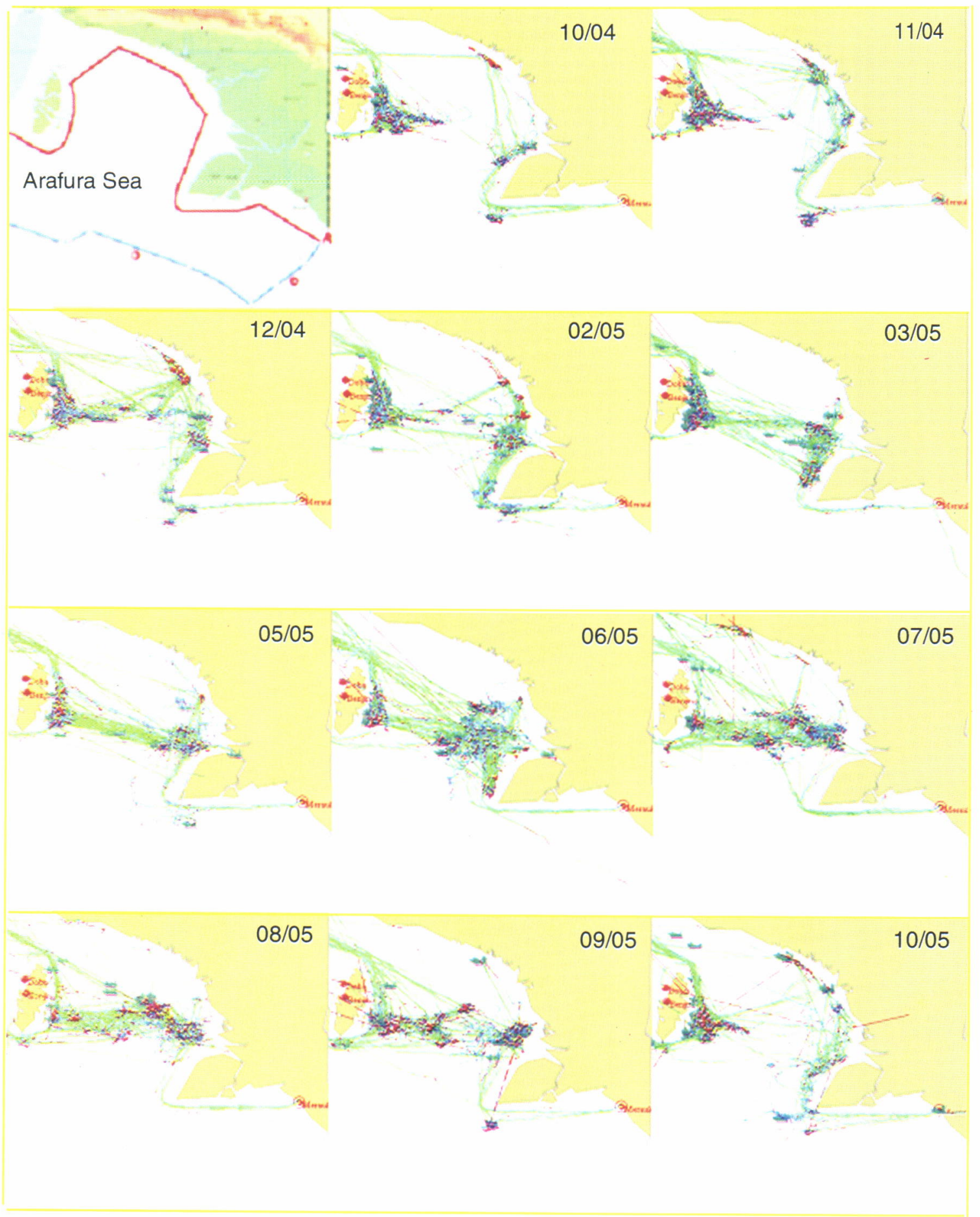


Appendix 2. The proportion of the vessels operating fish trawl without license, and the number of fish trawlers with and without license in the Arafura Sea, 1996-2005

\begin{tabular}{ccccc}
\hline Year & $\begin{array}{c}\text { Percentage of } \\
\text { fishing vessels } \\
\text { operated without } \\
\text { license }\end{array}$ & $\begin{array}{c}\text { Number of vessels } \\
\text { permitted to operate } \\
\text { fish trawl } \\
\text { (units) }\end{array}$ & $\begin{array}{c}\text { Estimated number of } \\
\text { illegal fish trawlers } \\
\text { (units) }\end{array}$ & $\begin{array}{c}\text { Total number of } \\
\text { fish trawlers } \\
\text { operated } \\
\text { (units) }\end{array}$ \\
\hline 1996 & 4.91 & 593 & 31 & 624 \\
1997 & 17.12 & 642 & 133 & 775 \\
1998 & 24.60 & 691 & 225 & 916 \\
1999 & 28.09 & 740 & 289 & 1,029 \\
2000 & 28.33 & 789 & 312 & 1,101 \\
2001 & 26.05 & 805 & 284 & 1,089 \\
2002 & 21.97 & 803 & 226 & 1,029 \\
2003 & 16.83 & 801 & 162 & 963 \\
2004 & 11.37 & 789 & 101 & 890 \\
2005 & 6.31 & 781 & 53 & 834 \\
\hline
\end{tabular}

Appendix 3. Effort and catch per unit effort in the Arafura shrimp fishery, 1996-2005

\begin{tabular}{|c|c|c|c|c|c|c|}
\hline \multirow{2}{*}{ Year } & \multicolumn{2}{|c|}{$\begin{array}{c}\text { Number of vessels } \\
\text { (units) }\end{array}$} & \multicolumn{3}{|c|}{$\begin{array}{l}\left.\text { Fishing effort }{ }^{*}\right) \\
\text { (units) }\end{array}$} & \multirow{2}{*}{$\begin{array}{c}\text { Catch of shrimps per } \\
\text { unit effort } \\
\text { (tonnes/year) }\end{array}$} \\
\hline & $\begin{array}{l}\text { Shrimp } \\
\text { trawlers }\end{array}$ & $\begin{array}{l}\text { Fish } \\
\text { trawlers }\end{array}$ & $\begin{array}{l}\text { Shrimp } \\
\text { trawlers }\end{array}$ & $\begin{array}{l}\text { Fish } \\
\text { trawlers }\end{array}$ & Total & \\
\hline 1996 & 431 & 624 & 431 & 156 & 587 & 77.20 \\
\hline 1997 & 336 & 775 & 336 & 194 & 530 & 85.50 \\
\hline 1998 & 399 & 916 & 399 & 229 & 628 & 73.70 \\
\hline 1999 & 463 & 1,029 & 463 & 257 & 720 & 63.09 \\
\hline 2000 & 526 & 1,101 & 526 & 275 & 801 & 57.49 \\
\hline 2001 & 458 & 1,089 & 458 & 272 & 730 & 57.89 \\
\hline 2002 & 408 & 1,029 & 408 & 257 & 665 & 63.41 \\
\hline 2003 & 406 & 963 & 406 & 241 & 647 & 68.54 \\
\hline 2004 & 331 & 890 & 331 & 223 & 554 & 84.80 \\
\hline 2005 & 301 & 834 & 301 & 208 & 509 & 89.53 \\
\hline
\end{tabular}

Remarks: ") Standardized in shrimp trawler units; fishing power of fish trawlers $=0.25$ of the fishing power of shrimp trawler 
